\title{
PENGEMBANGAN MEDIA INTERAKTIF BERBASIS PENEMUAN TERBIMBING 'TRANSGEO' PADA MATERI TRANSLASI UNTUK SISWA KELAS XI
}

\author{
Sebti Mardiana ${ }^{1)}$, Abd, Qohar ${ }^{2)}$ \\ ${ }^{1,2)}$ Pascasarjana Pendidikan Matematika Universitas Negeri Malang \\ Email: sebtimardiana@gmail.com ${ }^{1)}$,abd.qohar.fmipa@um.ac.id ${ }^{2}$
}

\begin{abstract}
The research is developmental research aimed to produce interactive media based on guided discovery learning on translation for XI grade students. Media is in form of webpages which embed flash file and Geogebra applet in presenting material. The research uses model of multimedia development by Alessi and Trollip. Validation test's result shows that media is valid with score of 76,25\%. In other hand, product trial to students and pupil shows that media is practicable with score of $84,46 \%$. Hence, media developed satisfies quality aspect namely valid and practicable. Research also shows that media can facilitate as well as motivate students' learning. The use of media especially by ulitizing mathematical software with discovery learning method is highly suggested to be applied in mathematics instruction.
\end{abstract}

Keywords: development, interactive media, translation, guided discovery

\section{PENDAHULUAN}

Geometri merupakan salah satu standar isi yang telah ditetapkan oleh NCTM dalam pembelajaran matematika. Geometri juga merupakan wadah yang mendukung standar proses penalaran dan pembuktian matematika siswa (NCTM, 2000). Adanya pembelajaran geometri dari jenjang sekolah dasar sampai sekolah menengah atas diantaranya bertujuan untuk mengembangkan kemampuan spasial, kemampuan melakukan pemodelan dan penyelesaian masalah dalam dunia nyata, keterampilan penggunaan teknologi secara spesifik dalam konteks geometri, sertasikap positif terhadap matematika (Jones, 2002).

Akan tetapi, praktek yang terjadi di lapangan menunjukkan bahwa geometri merupakan materi yang tidak disukai oleh siswa. Berdasarkan hasil wawancara pada beberapa siswa SMA di bimbingan belajar tempat peneliti bekerja, sebagian besar dari mereka tidak menyukai geometri dengan alasan bahwa geometri merupakan pelajaran yang sulit untuk dipahami. Simmer (2011) mengidentifikasi beberapa alasan siswa tidak menyukai geometri yaitu sikap negatif terhadap cara mengajar guru dan kesulitan dalam memahami dan menyelesaikan masalah geometri. Bahkan beberapa siswa yang suka matematika, secara khusus tidak menyukai materi geometri (Simmer, 2011). Hal ini menuntut adanya evaluasi terhadap penyajian pembelajaran geometri di sekolah.

Salah satu cara yang bisa digunakan untuk meningkatkan sikap positif dan pemahaman terhadap geometri adalah mendesain pembelajaran yang bermakna bagi siswa (Ogbuehi \& Fraser, 2007). Siswa perlu untuk mengetahui mengapa suatu teorema dalam geometri dapat berlaku serta untuk apa teorema tersebut digunakan. Penemuan terbimbing bisa digunakan sebagai alternatif untuk 
memenuhi kebutuhan tersebut (Novak \& Canas, 2007).Melalui penemuan terbimbing, siswa dapat secara aktif terlibat dalam pembelajaran (Lewis, 2006). Dalam penemuan terbimbing, siswa merumuskan masalah, mengumpulkan data, membuat dugaan, memeriksa kebenaran dugaan, kemudian menarik kesimpulan. Bimbingan dalam proses penemuan dapat dilakukan guru melalui penggunaan media (Heinich, Molenda, Russell, \& Smaldino, 2002).

Geogebra merupakan perangkat lunak matematika yang dapat digunakan sebagai media pembelajaran geometri. Geogebra mendukung pembelajaran aktif dan berorientasi masalah, meningkatkan eksperimen dan penemuan di kelas maupun di rumah (Majerek, 2014; Hohenwarter, Hohenwarter, \& Lavicza, 2009; Tran, N.G., Bui, \& Phan, 2014). Penggunaan Geogebra sebagai media pembelajaran dapat meningkatkan pemahaman siswa (Bu \& Schoen, 2011). Secara pedagogis, Geogebradapat berperan diantaranya untuk meningkatkan keterlibatan siswa dalam bereksplorasi, mendukung pengambilan keputusan, mengkonfirmasi dugaan dan menarik kesimpulan, dan meningkatkan belajar, kontruksi, serta refleksi matematis siswa (Bu, Mumba, \& Alghaza, 2011b). Penggunaan geogebra dalam pembelajaran mendukung salah satu tujuan pembelajaran geometri, yaitu keterampilan penggunaan teknologi.Penggunaan teknologi dalam pembelajaran itu sendiri dapat meningkatkan motivasi siswa dalam belajar matematika (Bakar, Ayub, \& Luan, 2010).

Berdasarkan uraian diatas, perlu dikembangkan suatu media interaktif yang dapat memfasilitasi siswa dalam memahami transformasi geometri melalui penemuan terbimbing menggunakan Geogebra.

\section{METODE PENELITIAN}

Pengembangan media interaktif dilakukan dengan menggunakan model pengembangan multimedia oleh Alessi dan Trolip (2001). Model ini terdiri dari tiga tahapan, yaitu perencanaan, perancangan, dan pengembangan. Berdasarkan model tersebut, dilakukan langkah-langkah penelitian sebagai berikut: (1) mengidentifikasi kebutuhan, tujuan, dan batasan, (2) mengumpulkan ide dan sumber, (3) mengembangkan prototype media, (4) merancang pembelajaran, (5) mengembangkan media dan perangkat pembelajaran, dan (6) melakukan evaluasi dan revisi.

Pada evaluasi dan revisi, dilakukan validasi dan uji coba terbatas. Validasi dilakukan oleh dosen pendidikan matematika pascasarjana Universitas Negeri Malang dan mahasiswa program magister pendidikan matematika Universitas Negeri Malang yang sedang menempuh materi media pembelajaran. Media diujicobakan melalui peerteaching dalam kuliah media pembelajaran kelas D program magister pendidikan matematika Universitas Negeri Malang angkatan 2015. Selain itu, media diujicobakan pada enam siswa. Enam siswa tersebut terdiri dari dua siswa kelas $\mathrm{X}$ yang belum pernah memperoleh materi transformasi geometri dan empat siswa kelas XI yang sudah pernah memperoleh materi tersebut namun masih mengalami kesulitan. Enam siswa tersebut berasal dari SMA negeri yang berbeda di kota Malang. Melalui validasi dan uji coba, diperoleh saran untuk revisi media.

Data yang didapatkan dari kegiatan validasi dan uji coba kemudian dianalisis secara kuantitatif dan kualitatif. Data kuantitatif digunakan 
untuk menentukan kevalidan dan kepraktisan. Untuk menentukan kevalidan media, dilakukan pencocokan skor yang diperoleh dalam angket validasi dengan Tabel 1. Kepraktisan ditentukan melalui hasil uji coba pada mahasiswa melalui peer teaching serta uji coba terbataspada siswa SMA. Media dikatakan praktis ketika hasil ujicoba menunjukkan media dapat dipergunakan dengan sedikit atau tanpa revisi. Sementara itu, prototype media, hasil observasi ketika uji coba melalui peerteaching, serta saran validator dan pengguna media (siswa dan mahasiswa) menjadi data yang dianalisis secara kualitatif. Media dianalisis secara kualitatif berdasarkan teori tentang media pembelajaran.

Tabel 1. Kriteria Kevalidan Media (Akbar, 2013)

\begin{tabular}{|c|c|}
\hline Persentase & Kriteria Validitas \\
\hline $85,01 \%-100,00 \%$ & Sangat valid \\
\hline $70,01 \%-85,00 \%$ & Cukup valid \\
\hline $50,01 \%-70,00 \%$ & Kurang valid \\
\hline $1,00 \%-50,00 \%$ & Tidak valid \\
\hline
\end{tabular}

HASIL PENELITIAN DAN PEMBAHASAN

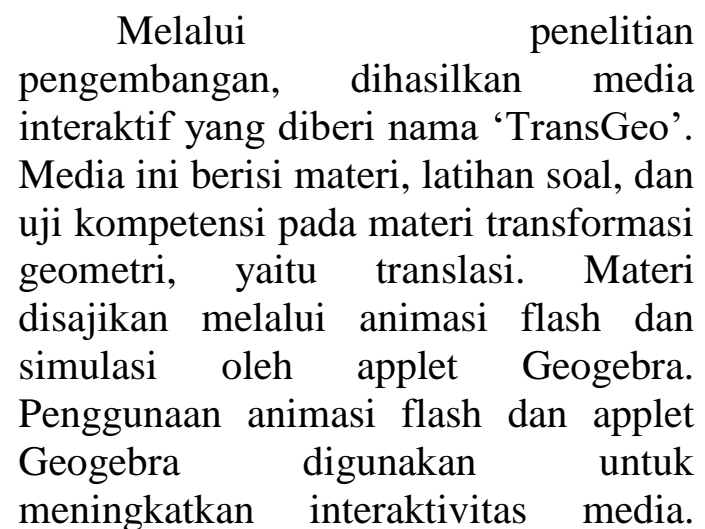
Selain itu, penggunaan applet Geogebra dapat meningkatkanvisualisasi yang berguna untuk memahami geometri (Bu \& Schoen, 2011).

Media berupa laman-laman web yang diakses menggunakan koneksi internet. Penggunaan laman-laman web daripada situs website digunakan untuk menjawab tantangan pelaksanaan onlinelearningdi Indonesia yaitu lambatnya koneksi koneksi internet (Hendrastomo, 2008). Walaupun penggunaan internet sudah tersebar luas di seluruh Indonesia, rata-rata kecepatan koneksi internet di Indonesiasangat rendah, yaitu urutan 104 di dunia(Akamai, 2015). Media TransGeo menggunakan internet untuk memproses applet Geogebra saja. Sedangkan elemen-elemen yang lain, yang memiliki ukuran file yang lebih besar, telah tersaji secara offline. Sehingga, hal ini meminimalir frustasi pada siswa karena menunggu proses loading media yang terlalu lama.

Media TransGeo yang dikembangkan memiliki limalaman utama, yaitu 'Home', 'Kompetensi', 'Materi', 'Latihan Soal', dan 'Uji Kompetensi'. Laman 'Home' berisi perkenalan singkat tentang media. Di dalam laman 'Home' diberikan gambar dan kalimat yang menarik perhatian siswa. Gambar yang ditampilkan merupakan gambar yang 'dekat' dengan kehidupan siswa sehingga siswa merasa lebih terlibat di dalamnya. Sementara itu, di laman 'Kompetensi', disajikan kompetensi dasar dan indikator yang termuat dalam media. Kompetensi dasar yang dimuat sesuai dengan kurikulum 2013 untuk bab transformasi geometri kelas XI. Kompetensi dasar ini memberikan gambaran pada siswa tentang apa yang dapat dipelajari dari media TransGeo. 
Pada laman 'Materi', siswa terlebih dulu memilih submateri yang ingin dipelajari. Submateri tersebut adalah translasi, refleksi, rotasi, dan dilatasi. Untuk sementara ini, hanya materi translasi dan refleksi yang telah divalidasi dan diujicobakan. Untuk masing-masing submateri, terdapat dua tampilan utama yaitu flash dan applet Geogebra. Siswa terlebih dahulu memperhatikan dan mengikuti instruksi yang ada dalam media flash.

Untuk submateri translasi misalnya, terlebih dahulu siswa diberikan ilustrasi tentang translasi dalam kehidupan sehari-hari, yaitu kegiatan menggeser-geser posisi lampu di atas lantai. Dengan demikian, siswa mendapatkan gambaran tentang translasi secara intuitif. Pemberian contoh dalam kehidupan sehari-hari membuat pembelajaran lebih bermakna bagi siswa dan membuat siswa mengapresiasi pengetahuan yang akan dipelajarinya.

Selanjutnya, siswa diinstruksikan untuk melihat translasi dalam matematika melalui eksplorasi geogebra.Di tahap inilah siswamulai mencoba untuk menemukan konsep translasi pada titik. Dimulai dengan proses mengamati, siswa kemudian menyusun hipotesis dan membuktikan dugaan mereka. Hal ini dilakukan berdasarkan petunjuk yang disajikan dalam flash yang berada tepat di sebelah applet Geogebra. Akhirnya siswa dapat menemukan konsep translasi dalam matematika. Serangkaian kegiatan menemukan konsep translasi yang dilakukan oleh siswa melalui penggunaan media sejalan dengan apa yang dimaksudkan dengan penemuan terbimbing atau guided discovery learning.Penggunaan penemuan terbimbing membuat siswa terlibat secara aktif dalam proses pembelajaran (Lewis, 2006). Hal ini tampak pula pada kegiatan uji coba media melalui peer teaching.

Setelah menemukan konsep tentang translasi pada titik, diberikan masalah tentang translasi pada garis. Masalah ini adalahextended problem atau pengembangan dari translasi pada titik.Masalah ini memungkinkan siswa untuk menggunakan konsep translasi pada titik yang baru saja dipelajari dengan materi persamaan garis lurus yang telah dipelajari sebelumnya. Hal ini dapat melatih keterampilan siswa dalam mengkoneksikan materi dalam matematika sekaligus membuat pembelajaran lebih bermakna bagi siswa.Untuk penggunaan media dalam setting kelas, extended problem ini bisadigunakan sebagai bahan untuk diskusi kelas secara keseluruhan. Siswa dapat bergantian menyampaikan pendapatnya tentang penyelesaian masalah tersebut.

Setelah merampungkan keseluruhan kegiatan dalam laman 'Materi', siswa dapat mencoba berlatih soal. Latihan soal diberikan untuk setiap submateri. Latihan soal berupa pilihan ganda. Masing-masing soal juga dilengkapi dengan pembahasan berupa langkah-langkah penyelesaian. Selanjutnya, siswa bisa mencoba uji kompetensi untuk menguji pemahaman mereka tentang keseluruhan materi dalam bab transformasi geometri.

Hasil validasi menunjukkan bahwa secara umum media cukup valid dengan persentase $76,25 \%$. Validator menyatakan bahwa materi dalam media sangat sesuai dan media mampu menunjang kegiatan belajar siswa dalam materi transformasi geometri. Namun, media perlu diperbaiki dalam hal kesesuaian ukuran dan tata letak gambar dan tulisan. Selain itu, validator juga menyarankan beberapa perubahan tampilan laman dan applet geogebra serta modifikasi cara penyajian 
ISSN 2089-8703 (Print) Vol. 6, No. 1 (2017)

ISSN 2442-5419 (Online)

pembahasan. Hasil validasi ditunjukkan

oleh Tabel 2.

Tabel 2. Hasil Validasi Media

\begin{tabular}{|l|c|c|}
\hline \multicolumn{1}{|c|}{ Penyataan } & Persentase & Kriteria \\
\hline Aspek Tampilan & & \\
\hline $\begin{array}{l}\text { a. Kemenarikan kombinasi } \\
\text { warna, tulisan, dan gambar }\end{array}$ & $75.00 \%$ & Cukup Valid \\
\hline $\begin{array}{l}\text { b. Kesesuaian ukuran dan } \\
\text { tata letak gambar dan } \\
\text { tulisan }\end{array}$ & $62.50 \%$ & Kurang Valid \\
\hline $\begin{array}{l}\text { c. } \text { Kemampuan media untuk } \\
\text { menunjang kegiatan } \\
\text { belajar siswa dalam materi } \\
\text { transformasi geometri }\end{array}$ & $87.50 \%$ & Sangat Valid \\
\hline d. Petunjuk penggunaan jelas & $75.00 \%$ & Cukup Valid \\
\hline $\begin{array}{l}\text { e. Warna, tulisan, dan } \\
\text { gambar menarik }\end{array}$ & $75.00 \%$ & Cukup Valid \\
\hline $\begin{array}{l}\text { f. } \text { Kalimat yang digunakan } \\
\text { jelas }\end{array}$ & $75.00 \%$ & Cukup Valid \\
\hline \begin{tabular}{l} 
g. $\begin{array}{l}\text { Media mudah untuk } \\
\text { dioperasikan }\end{array}$ \\
\hline Aspek Fungsi
\end{tabular} & $75.00 \%$ & Cukup Valid \\
\hline $\begin{array}{l}\text { a. Kesesuaian materi yang } \\
\text { disajikan media }\end{array}$ & $75.50 \%$ & Sangat Valid \\
\hline $\begin{array}{l}\text { b. Media mampu } \\
\text { memberikan bimbingan } \\
\text { pada siswa untuk } \\
\text { menemukan konsep } \\
\text { transformasi geometri }\end{array}$ & $75.00 \%$ & Cukup Valid \\
\hline $\begin{array}{l}\text { c. Media mampu memotivasi } \\
\text { untuk belajar matematika }\end{array}$ & $75.00 \%$ & Cukup Valid \\
\hline
\end{tabular}

Uji coba media pada siswa dan mahasiswa secara umum menunjukkan persentase $84,46 \%$, sehingga media dapat digunakan dengan sedikit revisi. Baik siswa maupun mahasiswa menganggap media menarik, mudah dioperasikan, dan dapat memotivasi dalam belajar matematika. Akan tetapi, mereka menyarankan penambahan tombol back pada tampilan flash serta memperjelas petunjuk penggunaan geogebra dalam proses penggunaan media. Hasil uji coba ditunjukkan oleh Tabel 3.

Berdasarkan saran dari validator dan pengguna media, dilakukan revisi pada media. Revisi yang dilakukan antara lain: (1) penggantian gambar pada slider pada halaman utama, (2) penambahan tombol kembali pada tampilan flash, dan (3) penambahan petunjuk dalam penggunaan geogebra. Dengan demikian, dihasilkan media dengan tampilan seperti pada Gambar 1 dan Gambar 2. 
ISSN 2089-8703 (Print) Vol. 6, No. 1 (2017)

ISSN 2442-5419 (Online)

Tabel 3. Hasil Uji Coba Media

\begin{tabular}{|l|c|c|c|c|}
\hline \multicolumn{1}{|c|}{ Pernyataan } & Mahasiswa & Siswa & $\begin{array}{c}\text { Rata- } \\
\text { rata }\end{array}$ & Kriteria \\
\hline Aspek desain & & & & \\
\hline $\begin{array}{l}\text { a. Petunjuk penggunaan } \\
\text { jelas }\end{array}$ & $80.00 \%$ & $79.17 \%$ & $79.58 \%$ & $\begin{array}{c}\text { Dapat digunakan } \\
\text { dengan sedikit revisi }\end{array}$ \\
\hline $\begin{array}{l}\text { b. Warna, tulisan, dan } \\
\text { gambar menarik }\end{array}$ & $90.00 \%$ & $87.50 \%$ & $88.75 \%$ & $\begin{array}{c}\text { Dapat digunakan tanpa } \\
\text { revisi }\end{array}$ \\
\hline $\begin{array}{l}\text { c. Kalimat yang digunakan } \\
\text { jelas }\end{array}$ & $82.50 \%$ & $79.17 \%$ & $80.83 \%$ & $\begin{array}{c}\text { Dapat digunakan } \\
\text { dengan sedikit revisi }\end{array}$ \\
\hline $\begin{array}{l}\text { d. Media mudah untuk } \\
\text { dioperasikan }\end{array}$ & $85.00 \%$ & $87.50 \%$ & $86.25 \%$ & $\begin{array}{c}\text { Dapat digunakan tanpa } \\
\text { revisi }\end{array}$ \\
\hline Aspek Fungsi & $82.50 \%$ & $83.33 \%$ & $82.92 \%$ & $\begin{array}{c}\text { Dapat digunakan } \\
\text { dengan sedikit revisi }\end{array}$ \\
\hline \begin{tabular}{l} 
a. $\begin{array}{l}\text { Media membimbing saya } \\
\text { dalam menemukan } \\
\text { konsep transformasi } \\
\text { geometri }\end{array}$ \\
\hline $\begin{array}{l}\text { b. Media membuat saya } \\
\text { bisa memahami } \\
\text { transformasi geometri }\end{array}$
\end{tabular} & $82.50 \%$ & $79.17 \%$ & $80.83 \%$ & $\begin{array}{c}\text { Dapat digunakan } \\
\text { dengan sedikit revisi }\end{array}$ \\
\hline $\begin{array}{l}\text { c. Media mampu } \\
\text { memotivasi saya untuk } \\
\text { belajar matematika }\end{array}$ & $92.50 \%$ & $91.67 \%$ & $92.08 \%$ & $\begin{array}{c}\text { Dapat digunakan tanpa } \\
\text { revisi }\end{array}$ \\
\hline
\end{tabular}

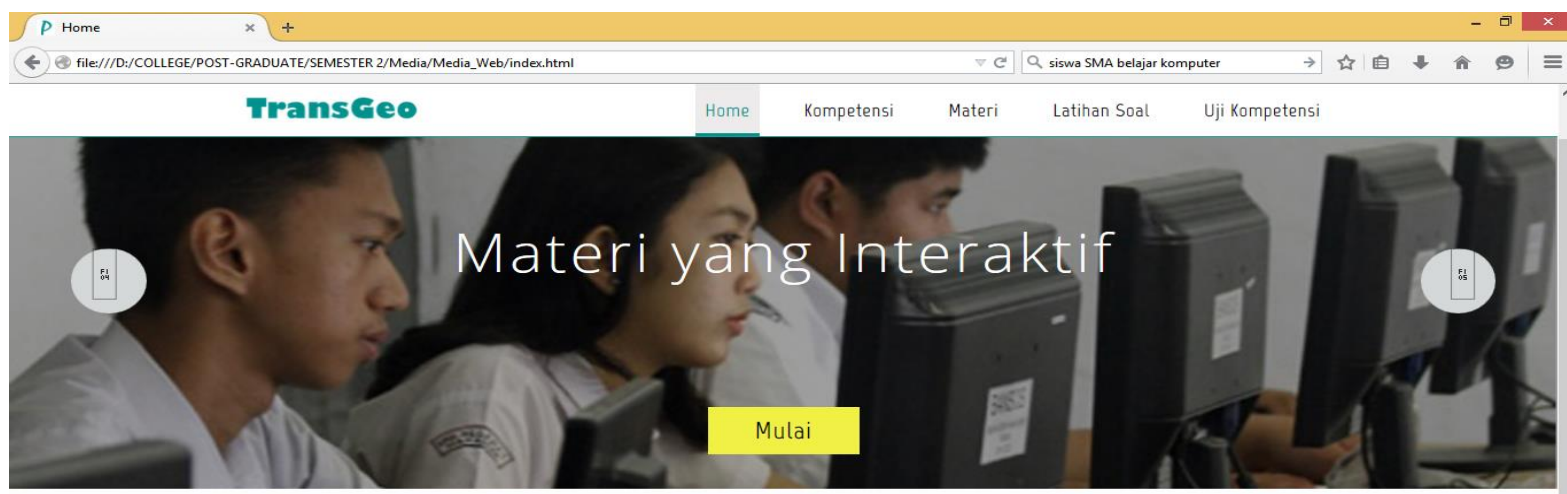

Selamat Datang di Media Interaktif TransGeo

Di media ini, kita akan belajar bersama materi transformasi geometri untuk kelas XI SMA.

Media ini dilenglapi dengan lathan soal dan uji kompetensi untuk mengembangkan pemahaman kita.

Gambar 1. Tampilan Laman 'Home' 


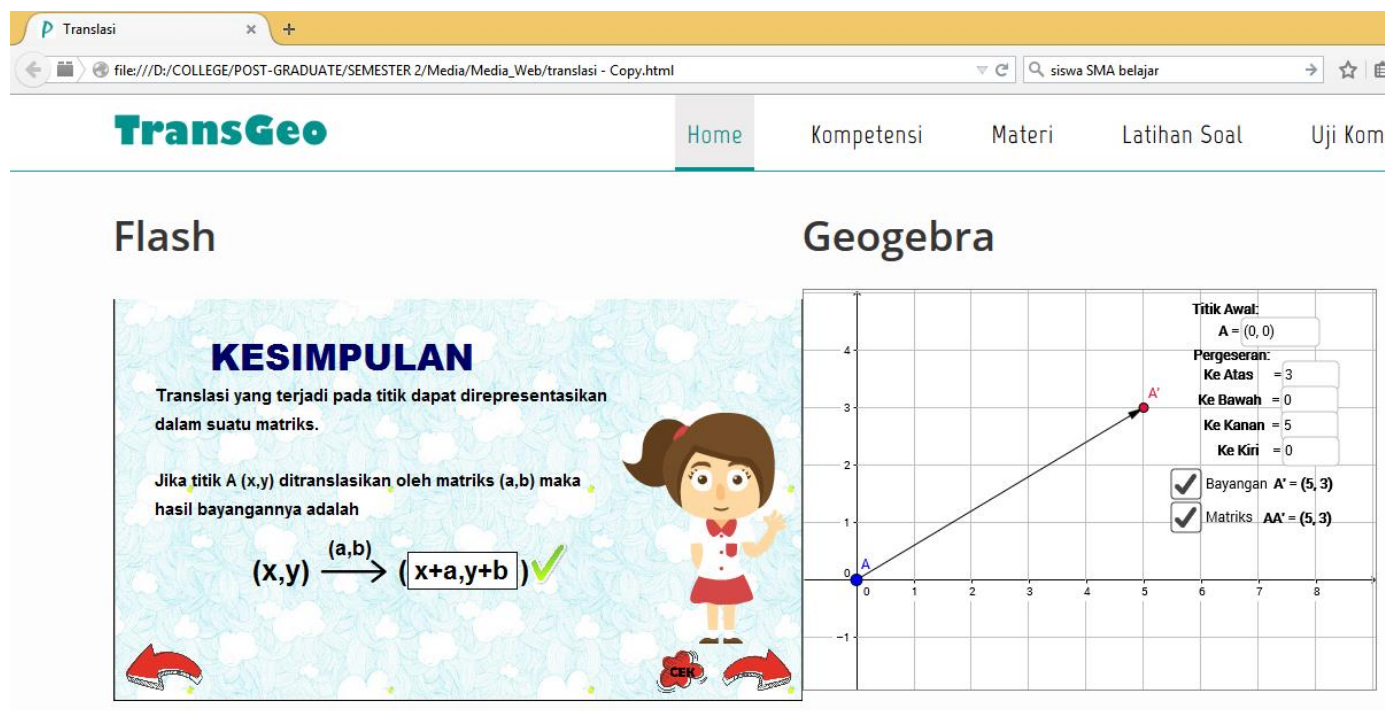

Gambar 2. Tampilan Laman Materi

Media TransGeo dapat digunakan oleh siswa secara mandiri ataupun digunakan dalam pembelajaran di kelas. Penggunaan media dalam setting pembelajaran di kelas menuntut skenario pembelajaran tertentu oleh guru. Temuan pada saat melakukan peer teaching menunjukkan bahwa meskipun media dirancang untuk memberikan bimbingan dalam proses penemuan terbimbing oleh siswa, guru tetaplah memegang peranan penting sebagai fasilitator, terlebih ketika siswa belum familiar dengan media berbasis komputer.Selain itu, karena sebagian besar kegiatan dilakukan di dalam media, guru perlu memberikan penugasan lain pada siswa untuk merekam apa saja yang telah dipelajari dalam bentuk fisik, misalnya dengan penugasan penulisan jurnal harian atau portofolio. Salah satu alternatif rancangan pembelajaran menggunakan media TransGeo terdapat pada lampiran.

\section{KESIMPULAN DAN SARAN}

Penelitian pengembangan yang dilakukan telah menghasilkan media yang valid dan praktis. Persentase kevalidan sebesar $76,25 \%$, sedangkan persentase kepraktisan sebesar $84,46 \%$. Penelitian juga menunjukkan bahwa media mampu menunjang kegiatan belajar siswa serta memotivasi siswa dalam belajar. Hasil penelitian pengembangan menyarankan pengoptimalan pemanfaatan perangkat lunak matematika sebagai media pembelajaran matematika di sekolah.

\section{DAFTAR PUSTAKA}

Akamai. (2015). Akamai's [State of the Internet] Q3 2015 Report Vol 8 No 3. Massachusetts: Akamai Technologies, Inc.

Akbar, S. (2013). Instrumen Perangkat Pembelajaran. Bandung: PT Remaja Rosdakarya.

Alessi, S., \& Trollip, S. (2001). Multimedia for Learning: Methods and Development. Boston: Allyn and Bacon.

Bakar, K., Ayub, A., \& Luan, W. T. (2010). Exploring secondary school students' motivation using technologies. Procedia 
Social and Behavioral Sciences 2, 4650-4654.

Bu, L., \& Schoen, R. (2011). ModelCentered Learning: Pathways to Mathematical Understanding. Rotterdam: Sense Publishers.

Bu, L., Mumba, F., \& Alghaza, Y. (2011b). Geogebra as a Pedagogical Tool: A Preliminary Taxonomy. Proceedings of the Second North American GeoGebra Conference, GeoGebra-NA 2011, June 17-18, 2011 (pp. 3240). Toronto: University of Toronto.

Heinich, R., Molenda, M., Russell, J., \& Smaldino, S. (2002). Instructional Media and Technologies for Learning. New Jersey: Pearson Education, Inc.

Hendrastomo, G. (2008). Dilema dan Tantangan Pembelajaran eLearning. Majalah Ilmiah Pembelajaran Vol 4 No 1.

Hohenwarter, J., Hohenwarter, M., \& Lavicza, Z. (2009). Introducing dynamic dathematics software to secondary school teachers: The case of GeoGebra. The Journal of Computers in Mathematics and Science Teaching 28(2), 135-46.

Jones, K. (2002). Issues in the Teaching and Learning of Geometry. In L. Haggarty, Aspects of Teaching Secondary Mathematics: Perspectives on Practice (pp. 121-139). London: RoutledgeFalmer.
Lewis, R. (2006). Discovery Learning in Mathematics Education: Using Multimedia Technology to Reach Teacher. Thesis. New York: Rochester Institue of Technology.

Majerek, D. (2014). Application of Geogebra for Teaching Mathematics. Advances in Science and Technology Research Journal Vol 8 No 24, 51-54.

NCTM. (2000). Principles and standards for school mathematics. USA: NCTM.

Novak, J., \& Canas, A. (2007). Theoretical Origins of Concept Maps. Reflecting Education Vol 3 No 1, 29-42.

Ogbuehi, P., \& Fraser, B. (2007). Learning Environment, Attitudes, dan Conceptual Development Associated with Innovative Strategies in MiddleSchool Mathematics. Leaning Environments Research Vol 10 No 2, 101-114.

Simmer, M. (2011). It's Not the Math They Hate. Hawaii University International Conferences On Mathematics and Engineering. Honolulu.

Tran, T., N.G., N., Bui, M., \& Phan, A. (2014). Discovery Learning with the Help of the Geogebra Dynamic Geomtery Software. nternational Journal of Learning, Teaching and Educational Research Vol. 7 No. 1, 44-57. 